\title{
Exploration on the Teaching Reform of International Marketing Course
}

\author{
ZHAO Yu \\ Beijing Institute of Petrochemical Technology, Beijing \\ LI Ji \\ Harbin Institute of Technology, Harbin \\ LIU Zhuohui \\ Harbin University of Finance, Harbin \\ LIU Feier, PAN Min \\ Beijing Institute of Petrochemical Technology, Beijing
}

\begin{abstract}
Any enterprise is likely to be affected by international market whether it goes to the world or not. Faced with serious challenge, the domestic enterprise is in urgent need of international marketing talents cultivated through higher education. Moreover, with another step in the history development of our national higher education business, the teaching of international marketing course should keep pace with the development and reform of higher education to implement teaching reform to international marketing course of economy and management specialties such as marketing, international trade, etc. In this background, combined actual teaching situation, this paper analyzes major problems in the teaching of current international marketing course and presents corresponding suggestions on teaching reform from three aspects, namely teaching material system, practice teaching link, teaching methods and means.
\end{abstract}

KEYWORD: International marketing; teaching reform; higher education

At present, the business activities of most enterprises of various countries, such as investment, production, marketing, distribution, etc., are brought into the global scale. Any enterprise is likely to be affected by the international market whether it goes to the world or not. Faced with serious challenges, the domestic enterprise is in urgent need of the international marketing talents cultivated through higher education. As a professional basic course of International Economics \& Trade Program and Marketing, international marketing course is a foreign customer-oriented science to research international enterprise management and engage in international marketing activities, and it is also the extension and application of basic marketing and forms a branch. The course features comprehensiveness, marginality, practicality, artistry. International marketing is a modern management application discipline based on philosophy, mathematics, economics, behavioral science, modern management theory and international trade [1].

With another step in the history development of our national higher education business, the teaching of international marketing course should keep pace with the development and reform of higher education to implement teaching reform to international marketing course of economy and management specialties such as marketing, international trade, etc. Combined the actual teaching situation, this paper will present some views on the teaching reform of international marketing course.

\section{PROBLEMS IN THE TEACHING OF INTERNATIONAL MARKETING COURSE}

The teaching of our international marketing course is short of characteristic in the construction of teaching material. In addition, the practical teaching is not valued, and the teaching methods and means should be improved, which is also a problem generally existed in the teaching of current international marketing course.

\subsection{Short of characteristic in the construction of teaching material}

The economics teaching material of Gregory Mankiw - an American economist - sweeps around the world because the material written by him explains profound theories in simple language and is popular and easy to understand. This is exactly the fundamental starting point and guiding ideology of compiling international marketing teaching material. At present, the teaching material of international marketing in our country is strong in theory, and short of readability and interestingness which is 
exactly the attractive point of foreign excellent marketing teaching material [2].

\subsection{Not valued practical teaching}

The foreign higher education attaches importance to the cultivation of practical link. Its various practical teaching means and methods are perfect, from case teaching to teacher-student interaction, teaching base, etc. Nowadays, in mostly domestic colleges and universities, the teaching of international marketing course adopts traditional teaching method, namely that the theory is valued and the practice is neglected. The main performance of this phenomenon covers three aspects. First, the training objective and teaching program only emphasize the importance of theoretical course, and not pay attention to the cultivation of students' practical ability. Secondly, there is no guarantee for the practical teaching time, and the teaching link is less and simple. In teaching, the theoretical teaching time occupies lots of class hours, but the practical teaching time is short and the class hour for practical teaching is less; because of the limitation of teachers, sites, facilities, class hours, etc, the practical teaching cannot form a system, and there are few colleges and universities which can launch practical teaching. Thirdly, the teachers who instruct in this course are mostly used to traditional theoretical teaching mode, thus this course lacks of teachers with rich practical experience.

\subsection{The teaching methods and means should be improved}

The teaching methods and means are the core content of teaching reform. In the teaching of international marketing course of colleges and universities, many teachers still follow the traditional classroom lecture to impart knowledge, and neglect that the international marketing is a professional course with strong practicality, contingency and comprehensiveness. On one hand, the traditional teaching method has a low requirement to the practical ability of teacher, and still adopts cramming method to impart knowledge; on the other hand, due to the limitation of many factors, the teaching mean of this course is very simple in many colleges and universities, which cannot meet the need of modern teaching. Whether multimedia teaching, case teaching, or simulation training, flexible and diverse methods must be adopted to improve the student's specialized knowledge and practical professional competence.

\section{SUGGESTIONS ON THE TEACHING REFORM OF INTERNATIONAL MARKETING COURSE}

\subsection{Construct interesting teaching material with Chinese characteristics}

The author considers that the construction and reform of teaching system is an important and profound educational reform innovation. Nowadays, some specialists and scholars have put forward views about this. For the construction and reform of the teaching material system of international marketing course, the author considers that the principals and teachers of international marketing course of various colleges and universities should compile interesting teaching material of international marketing course with Chinese characteristics on the basis of serious discussion and investigation, through combining its own professional features and the teaching reform project study between colleges and universities [3].

\subsection{Improve practical teaching content}

In order to improve the teaching quality of international marketing course, the reform must be carried out to the practical teaching, and the practice should be taken as the goal while setting the training objective. Practice is the application of theory, and we should increase the proportion of practical teaching and improve the ability of students to analyze and solve problems and the operational ability in the premise of assuring necessary and enough theoretical knowledge. For the arrangement of practical teaching content, we can follow the sequence from simple to complicated, from elementary to advanced, from class exercise to practical training, and conduct step by step. In addition, the teachers who teach this course should utilize various opportunities from society and school to improve their own practical abilities and try hard to become "double capability trainer" talents.

\subsection{Teaching methods and means}

The teaching content of international marketing course has close relation with practical life. If a teacher lectures alone in the whole class, the students may feel boring and lose interest to learn. In order to make the students better understand and acquire theoretical knowledge, the teachers can adopt the method liked by students to impart the teaching content, such as heuristic modes of teaching, imagery thinking and others to induce the interest of students to learn theory knowledge, and combine interactive teaching to develop the students' initiative and encourage the students to think independently and discuss in class. In addition, the teachers should actively carry out case teaching 
method and mix the theory knowledge of international marketing course into practical case to teach to make the students acquire key points and difficult points with ease. And the teacher should employ simulation case study, empirical case study in teaching through combining actual situation to improve the students' practical application ability and scientific research ability. Finally, in order to improve teaching quality and efficiency, the teachers should continuously explore and utilize modern teaching methods, expertly use multimedia technology to assist the teaching. The teachers can make the teaching content into vivid and visual multimedia courseware by adopting modern computer technology, and use slide show, projection, recording, television, computer and other multimedia facilities to carry out demonstration teaching. Such teaching method can make the students acquire lots of empirical documentation and information in short time, and also make the students to learn knowledge and expand thought while enjoying dynamic, static picture, music, video.

\section{CONCLUSIONS}

With the development of our higher education business, the teaching reform is a problem which is valued by various specialties in current colleges and universities, and as a professional basic course of economy and management specialties such as marketing, international trade, the teaching reform of international marketing is also a teaching job which should be continuously deepened and improved. In order to adapt to rapidly developed external situation and meet high requirement of our country to the talents in economy and management specialties, we should combine the construction of teaching material, teaching content, teaching method and means to make the students become high-quality talents who can know the basic theory of international marketing and can also apply theoretical knowledge to carry out practical application.

\section{ACKNOWLEDGEMENT}

This paper was funded by these projects: SchoolLevel Teaching Reform Project of Beijing Institute of Petrochemical Technology — Reform and Practice of Simulation Case Teaching Method of International Marketing Course

\section{REFERENCES}

[1] WANG Rong, SUN Liping, Research on Ability TrainingBased Teaching Reform of International Marketing, Journal of Southwest Agricultural University (Social Science Edition), Issue 11, 2011.

[2] ZHANG Nan, Suggestions on the Teaching Reform of International Trade Theory and Practice in the Background of Globalization, The Science Education Article Collects (the early ten days periodical), Issue 3, 2010.

[3] JIANG Yonghong, Primary Exploration on International Marketing Teaching Reform of Shaanxi International Business College, Shandong Industrial Technology, Issue $15,2013$. 